\title{
A história da imigração italiana no Rio Grande do Sul em álbuns comemorativos
}

The history of Italian immigration in Rio Grande do Sul in commemorative albums

Tatiane de Lima* tatiane.delima@yahoo.com.br

Resumo: O presente artigo propõe um breve estudo comparado entre três álbuns comemorativos dedicados à imigração italiana no Rio Grande do Sul. Queremos, a partir da comparação, identificar e analisar as semelhanças e diferenças que há na história da imigração italiana que é contada em cada um destes suportes de memória.

Palavras-chave: álbuns comemorativos, imigração Italiana, Rio Grande do Sul, História Comparada

Abstract: This paper presents a brief comparative study of three commemorative albums devoted to Italian immigration in Rio Grande do Sul. We want, from the comparison, identify and analyze the similarities and differences there are in the history of Italian immigration that is counted in each one of the albums.

Keywords: commemorative albums, Italian immigration, Rio Grande do Sul, comparative History

* Mestranda em História pela Universidade do Vale do Rio dos Sinos (UNISINOS), bolsista PROSUP/CAPES. Professora na rede municipal de ensino de Novo Hamburgo/RS 
Este estudo trata de sujeitos: os imigrantes italianos. Trata também de maneiras de lhes representar: através de fotografias e narrativas. E de objetos para guardar histórias e memórias: os álbuns comemorativos. Estes álbuns podem ser entendidos como suportes de memória, e nesta investigação em especial, se dedicam às lembranças da imigração italiana no Rio Grande do Sul. Téllez (1998) em sua obra sobre álbuns de família nos apresenta a perspectiva de entendê-los - ainda que este estudo trate de álbuns comemorativos - enquanto sua função arquivística e narrativa, já que eles guardam e contam histórias de um determinado grupo, a partir de imagens e textos.

Os objetos selecionados para este estudo são o Álbum Comemorativo do $75^{\circ}$ Aniversário da Colonização Italiana no Rio Grande do Sul, o Álbum do Centenário da Imigração Italiana e o Álbum Cultura Italiana 130 anos. Todos os três álbuns têm como característica principal sua designação comemorativa, pois foram criados no bojo dos festejos de datas de aniversário de chegada dos imigrantes italianos ao Rio Grande do Sul.

O primeiro álbum, dedicado aos 75 anos da imigração italiana, editado pela Revista O Globo, foi publicado no contexto das comemorações da Festa da Uva em Caxias do Sul no ano de 1950. Esta festa estava sendo retomada após 13 anos de recesso devido à Segunda Guerra Mundial, e atraiu mais de 100 mil pessoas a Caxias do Sul, contando com a presença do Presidente General Eurico Gaspar Dutra e do Governador Valter Jobim. A comemoração teve o apoio dos governos federal, estadual e municipal, e se organizou através de uma Comissão Coordenadora da Festa da Uva e Exposição Agroindustrial ${ }^{1}$. Houve também subcomissões em cada um dos distritos da cidade de Caxias do Sul, com o fim de facilitar a comunicação entre os dez municí$\operatorname{pios}^{2}$ que representavam a italianidade durante os festejos. Problemas financeiros colocaram em risco a realização do programa festivo estabelecido pela Comissão Coordenadora, que mesmo contando com o apoio governamental precisou recorrer ao auxílio dos Poderes Executivo e Legislativo. Com o ocorrido, a Prefeitura de Caxias do Sul cedeu um crédito de um milhão de cruzeiros. Ainda não sendo suficiente este valor, se recorreu ao projeto de auxílio que estava em votação na Câmara Federal, e através do Senador Salgado Filho e do Deputado Café Filho se elevou a 9 milhões de cruzeiros a verba, que possibilitou a construção dos pavilhões da exposição, o lançamento deste álbum e as demais iniciativas, podendo a festa ser realizada sem danos à sua pré-organização.

O segundo álbum foi lançado devido ao Centenário da Imigração Italiana durante as comemorações do Biênio da Colonização e Imigração do Rio Grande do Sul em 1975, um momento criado para rememorar a história da imigração. As comemorações foram promovidas pelo governo do estado, e tinham por fim homenagear os grupos imigrantes entendidos como a base da formação da população rio-grandense. Nas celebrações, a memória imigrante foi recuperada a partir de três correntes imigratórias que receberam maior destaque no decorrer das festividades: açorianos, alemães e italianos. Outras correntes imigratórias ${ }^{3}$ também foram homenageadas durante as comemorações. A participação italiana nos festejos do Biênio da Colonização e Imigração se deu através da instalação oficial da Comissão Executiva dos festejos do Centenário da Imigração

\footnotetext{
${ }^{1}$ Comissão: Presidente Júlio Ungaretti - Primeiro Vice-Presidente: Padre Eugênio Giordani - Segundo Vice-Presidente: Joaquim Pedro Lisboa - Secretário Geral: Moacyr Rodrigues de Oliveira - Tesoureiro Geral: Arthur Rodolfo Rossarola, Vinicius Ribeiro Lisboa, Francisco Menegat e Caetano Mancuso - Conselho Consultivo: Demétrio Niederauer, Nestor Rizzo, João José Conte, Ítalo Agostinelli, Antônio Boff e Honório Marotto.

${ }^{2}$ Caxias do Sul, Flores da Cunha, Farroupilha, Antônio Prado, Bento Gonçalves, Garibaldi, Veranópolis, Nova Prata, Guaporé e Encantado.

${ }^{3}$ Argentinos, Espanhóis, americanos, franceses, ingleses, israelitas, japoneses, libaneses, poloneses, uruguaios e também negros e índios.
} 
Italiana $^{4}$, e também de grupos de trabalho para assuntos específicos. Esta Comissão propôs iniciativas festivas de cunho social, cultural e econômico contando com o apoio do governo italiano para sua realização. As proposições incluíam o compartilhamento de cópias documentais acerca da imigração italiana no estado, doação de réplicas de obras de arte de renome, palestras e conferências, apresentações musicais eruditas e populares, peças de teatro, festivais de cinema, missões econômicas, construção de monumentos, exposições de arte e edições de livros, como é o caso do álbum.

Por fim, o terceiro álbum foi promovido pela Souza Cruz no ano de 2005 e realizado em razão dos 130 anos de chegada dos imigrantes italianos, sendo lançado na $51^{\text {a }}$ Feira do Livro de Porto Alegre. A comemoração foi aberta oficialmente pelo Governador Germano Rigotto, pelo Embaixador da Itália no Brasil Michele Valensise e pelo Cônsul-Geral do Estado Mário Pannaro, com o acendimento de um Fogo Simbólico da Imigração, onde cada uma das cidades ligadas à imigração italiana no estado ficaria responsável pelo recebimento de uma centelha. A festa foi organizada pela Secretaria Municipal de Educação, Cultura e Desportos de Farroupilha e pelo Comitê Executivo da Etnia Italiana. Se estabeleceu um calendário de trabalho contando com o apoio da Embaixada italiana no Brasil, sendo a mais importante finalidade desta comemoração reforçar o turismo e os negócios entre Brasil e Itália.

Podemos inferir que o contexto comemorativo em que foram produzidos estes álbuns nos revela muito de suas ambições. Em linhas gerais eles se prestaram a homenagear e agradecer aos imigrantes italianos pela contribuição para a prosperidade do Rio Grande do Sul e também guardar a memória da imigração italiana do estado.
Este sentimento de júbilo que é trazido pelas comemorações encontra-se muito presente nos três álbuns, em fotografias e narrativas que mostram a prosperidade alcançada pelas cidades ligadas à imigração italiana. Apresentam também pessoas, famílias e políticos, bem como fábricas e indústrias, por meio desta mesma preleção. O imigrante é homenageado nos álbuns em depoimentos e discursos onde o agradecimento àqueles que prestaram seus serviços para o desenvolvimento destas terras encontra-se muito presente por meio da retomada da história italiana do estado caracterizada como epopeia. Portanto, o ser imigrante é exaltado à medida em que os gaúchos reconhecem seus feitos nos mais variados aspectos, como: social, cultural, político e econômico, a partir das homenagens nas comemorações.

Contudo, não se trata apenas de homenagear e guardar lembranças, mas principalmente de classificálas e selecioná-las para que componham de maneira organizada uma mensagem que se quer transmitir. Sobre a seleção de memórias Candau (2013, p. 137) questiona: "a memória, pessoal ou coletiva, empenha-se constantemente em organizar e reorganizar o passado. Porque é que os governos, os partidos políticos, os grupos de pressão não haviam de tentar infletir esse processo numa direção que lhes fosse favorável?". Desta forma, se destitui a ideia de que as memórias contempladas nos álbuns são meras seleções aleatórias, e assim concordamos com o que afirma Traverso (2012, p. 24): "a memória, individual ou coletiva, é uma visão do passado que é sempre filtrada pelo presente".

Os álbuns, como já dito anteriormente, prestamse também como forma de guardar a memória e identificar o estado do Rio Grande do Sul como detentor deste passado imigrante. Passado este que engrandece o

\footnotetext{
${ }^{4}$ Presidente - Ottoni Adelino Zatti Minghelli; Vice-Presidentes - Aristides Amadeo Germani, Moisés Michelon, Enio Lippo Verlangieri e Oddone Marsiaj; Tesoureiro - Luiz Mandelli; Secretário Geral - Mário Bernardo Sesta; Secretária Secretária Geral - Lourdes Maria Fellini Sartor; Membro Honorário - Dr. Renato Rabby, Cônsul Geral da Itália.
} 
estado, que dá-se a ler como um lugar acolhedor de todas as gentes, que tiveram suas especificidades respeitadas, e sua tradição agregada à cultura rio-grandense. Nesta perspectiva Roehe (2005, p. 63), afirma que "E é nesse sentido, que se acredita na identificação do álbum como um mecanismo de propaganda, estampando, em suas páginas, o desenvolvimento dos imigrantes e seus descendentes $[\ldots]$."

Contudo, nem só de narrativas escritas são compostos os álbuns, mas de textos imagéticos, que também podem ser entendidos enquanto narrativas, já que contam uma história, possuindo personagens, trama e sentido. Sobre o uso de imagens Pesavento (2008, p. 99) afirma que:

Certamente, as imagens são, e tem sido sempre, um tipo de linguagem, ou seja, atestam uma intenção de comunicar, que é dotada de um sentido e é produzida a partir de uma ação humana intencional. $E$, nessa medida, as imagens partilham com as outras formas de linguagem a condição de serem simbólicas, isto é, são portadoras de significados para além daquilo que é mostrado.

Neste estudo, a proposta de uma abordagem comparada entre os álbuns comemorativos da imigração italiana no Rio Grande do Sul se dá a partir da perspectiva trazida por Barros (2014) ao longo de sua obra sobre o tema. Ele afirma que "comparar é uma forma específica de propor e pensar questões" (2014, p. 17), e nesse sentido a comparação traz à tona as diferenças $\mathrm{e}$ semelhanças, possibilitando análises mais profundas e sistematizadas. É importante ter em mente o que se comparar e de que maneira, sendo estas construções do próprio historiador e não uma "fórmula" prédeterminada. Neste estudo se fará uso da História Comparada, pois ela irá nos ajudar a examinar determinados problemas atravessando três realidades históricas distintas (BARROS, 2014, p. 143). Tomaremos as precauções necessárias para não corrermos o risco de propor anacronismos ou leituras forçadas a partir de paradigmas criados para avaliar aproximações e afastamentos.

No presente trabalho faremos referência aos termos colonização e imigração. Entendemos imigração na perspectiva de Sayad (1998, p. 15) que afirma que "a imigração é, em primeiro lugar, um deslocamento de pessoas no espaço [...] físico", sendo então o imigrante percebido como estrangeiro e de estadia provisória no país que o adota. Já o termo colonização, se refere aos colonos que se estabeleceram e contribuíram política, social e economicamente, conforme a definição de Bosi (1992, p. 11-12):

Colo significou, na língua de Roma, eu moro, eи ocupo a terra, e, por extensão, eu trabalho, eu cultivo o campo. Um herdeiro antigo de colo é incola, o habitante; outro é inquilinus, aquele que reside em terra alheia. Quanto a agrícola, já pertence a um segundo plano semântico vinculado à ideia de trabalho. A ação expressa nesse colo, no chamado sistema verbal do presente, denota sempre alguma coisa de incompleto e transitivo. E o movimento que passa, ou passava, de um agente para um objeto. Colo é a matriz de colônia enquanto espaço que se está ocupando, terra ou povo que se pode trabalhar e sujeitar. Colonus é o que cultiva uma propriedade rural em vez do seu dono; o seu feitor no sentido técnico e legal da palavra.

Com tema, objeto e metodologia definidos, propomos neste estudo analisar os álbuns entendendo-os como fontes de pesquisa. Neles, tanto a seleção de imagens quanto a escrita dos textos podem ser entendidos como atos políticos, já que foram devidamente selecionadas por seus autores para estarem ali, comunicando algo.

A questão chave que buscaremos responder é: que história da imigração italiana no Rio Grande do Sul é contada nos álbuns comemorativos lançados em diferentes épocas? Os desdobramentos destas questões levarão em consideração, a partir do já exposto em relação à metodologia a ser utilizada, se nas diferentes co- 
memorações com alguns anos de distância entre uma e outra houve diferenças ou aproximações no modo de narrar a história imigrante italiana do estado.

\section{Álbum Comemorativo do $75^{\circ}$ Aniversário da Colonização Italiana no Rio Grande do Sul}

O álbum do $75^{\circ}$ aniversário da imigração italiana no Rio Grande do Sul, organizado por Henrique D’ávila Bertaso e Mário de Almeida Lima, escrito em português e com imagens em preto e branco possui características de uma revisão histórica da imigração italiana no estado. Logo em suas primeiras páginas temos a explicitação dos objetivos propostos para a obra:

a finalidade deste álbum é exatamente apresentar um retrospecto da colonização italiana no Rio Grande do Sul, focando suas consequências na geografia e etnografia, na vida religiosa, cultural e econômica da área colonizada. [...] Procurando, pois, passar em revista 75 anos de trabalho construtivo da colonização italiana neste estado, apresentamos esta publicação associando-nos as justas homenagens tributadas a essa parcela da nacionalidade. (LIMA; BERTASSO, 1950, p. 5)

Este álbum composto por 521 páginas corresponde ao que se propõem: prestar uma homenagem aos imigrantes e descentes através da "contação" da história da imigração italiana, desde a vinda para o Rio Grande do Sul, seu período de instalação e do progresso adquirido pelo trabalho. A história da imigração italiana é contada a partir da chegada, passando pelo desbravamento das terras, a criação de lavouras e atividades fecundas, a afirmação de um produto típico - a uva -, que mais tarde fora transformada em vinho, um motivo de orgulho. Se dá maior ênfase para a Feira Agroindustrial e a Festa da Uva a se realizar, já que elas estão sendo retomadas após longo tempo de recesso. O álbum também é composto pela transcrição de discursos de inúmeros agentes políticos, como o Ministro Exterior da
Itália, o Cônsul-Geral da Itália e o Embaixador da Itália no Brasil. O colono aparece, conforme o álbum, como um "plantador de cidades". Esta expressão antecede a sucessão de páginas que irá listar e mostrar as cidades ${ }^{5}$ ligadas a imigração italiana e eleitas naquele momento como representativas da italianidade. Sobre as cidades se fala de seus aspectos econômicos, através do crescimento das mesmas pelas indústrias de sucesso que se estabeleceram nas mãos dos imigrantes. $\mathrm{O}$ imigrante italiano aparece como um trabalhador, que possui uma vida modesta, vivendo sem conforto, mas com a mesa farta.

As imagens do álbum, em preto e branco, priorizam os grandes atos celebrativos das comemorações. A tradição e cultura italiana aparecem nas imagens através de colheitas de uva e trigo.

\section{Álbum do Centenário da Imigração Italiana}

O álbum do centenário da imigração italiana define seus objetivos como:

esta obra pretende retratar a epopeia vivida pelos primeiro imigrantes italianos que chegaram ao Rio Grande do Sul, no final do século passado. Deseja, ainda, [...] ressaltar a rapidez com que os peninsulares se integraram ao nosso meio. [...] feliz, pois, sem dúvida, essa iniciativa do governo rio-grandense - o Biênio da Imigração - graças a qual todos nós podemos render homenagens a quantos escolheram esta parte do Brasil para aqui construirem a sua vida. (DUARTE, 1975, p. 3)

Retratar o que o álbum chama de epopeia da imigração italiana e render homenagens é o que se fez ao longo das 383 páginas. Neste sentido se conta a história do processo imigratório, culminando em progresso, que é apresentado através da publicidade de indústrias. A ascendência cultural dos descendestes dos primeiros imigrantes mostra-se como uma atualização do sucesso

\footnotetext{
${ }^{5}$ Garibaldi, Flores da Cunha, Antônio Prado, Guaporé, Bento Gonçalves, Caxias do Sul, Encantado, Farroupilha, Nova Prata e Veranópolis.
} 
da empreitada imigratória, e é apresentada através de aspectos como a música, as artes, a educação e a religião. O álbum também mostra como os imigrantes se integraram facilmente a nova realidade que lhes foi apresentada, e como se inseriram na História do Brasil, na política e na administração. A transcrição de vários discursos proferidos por políticos como o então Presidente Ernesto Geisel e o Governador Sinval Guazelli também compõem o álbum, pois eles fizeram parte das comemorações ao Centenário da imigração italiana, do qual a obra é fruto. Os produtos do trabalho do imigrante italiano também ganham destaque como o trigo, a uva e o vinho. $\mathrm{O}$ número de cidades ${ }^{6}$ representativas da imigração italiana neste álbum aumenta em relação ao anterior.

As imagens do álbum, desta vez coloridas, retratam principalmente a Festa da Uva, motivo de orgulho para os descendentes de italianos. Imagens panorâmicas das cidades mencionadas, bem como inúmeras propagandas de indústrias nelas localizadas apresentam o progresso. A tradição se faz presente pelas imagens de colonos lidando com a terra, colhendo uvas e produzindo vinhos. A presença de políticos no âmbito das comemorações também ganhou destaque nas imagens.

\section{Álbum Cultura Italiana - 130 anos}

O álbum referente aos 130 anos da imigração italiana no Rio Grande do Sul se propõem a

...no transcurso dos 130 anos da imigração italiana, é mais que apropriado o registro dessa presença que se estende até os dias de hoje, contribuindo para a identidade brasileira. Aos italianos e descendentes, a Souza Cruz felicita-os pela comemoração deste singular progresso e agradece a feliz ideia de terem adotado o Rio Grande do Sul e o Brasil como lar e pátria, cuja contribuição esta perenizada nas páginas desta obra.
(SULIANI; COSTA, Orelha do livro, 2005).

Em 339 páginas, onde a primeira metade é escrita em português e a segunda em italiano, se desenrola a história da imigração italiana. $\mathrm{O}$ álbum inicia com mensagens de políticos como o Governado Germano Rigotto, da Secretaria de Cultura, do Embaixador e do Cônsul da Itália. Este álbum por ser menor em número de páginas (por estar dividido em duas línguas) traz apenas alguns aspectos da imigração italiana no estado. Escrito por pesquisadores conhecidos nos estudos da imigração italiana, ele apresenta esta história a partir de novas perspectivas, como a mulher imigrante, ou de pesquisas consolidadas, entendendo o imigrante como aquele que veio "Fazer a América". Ainda aparecem aspectos sobre a agricultura, comércio, indústria, política, igreja, artesanato, literatura e culinária.

As imagens são o grande diferencial deste livro. Em alta resolução e ganhando um espaço próprio intitulado "a história da imigração italiana em imagens", ela mescla fotos antigas de colonos e suas famílias com fotos atuais. Em uma brincadeira de cores (coloridas, preto e branco e sépia) as imagens se confundem em relação a sua temporalidade. Obras de arte que retratam a imigração também ganham espaço.

\section{Considerações Finais}

A partir do exposto referente aos três álbuns, podemos concluir que todos apresentam um tom laudatório em relação à colonização italiana no Rio Grande do Sul, entendendo-a como pioneira, e sendo reconhecido o progresso das cidades ligadas a esta corrente imigratória. A composição dos álbuns, tanto na escrita quanto nas imagens são muito próximas, havendo o resgate de elementos tradicionais da cultura italiana.

\footnotetext{
${ }^{6}$ Farroupilha, Silveira Martins, São Borja, Nova Prata, Caxias do Sul, Arvorezinha, Encantado, Garibaldi, Carlos Barbosa, Nova Araçá, Casca, Serafina Corrêa, Parai, Nova Bréscia, Marau, São Marcos, Nova Bassano, Bento Gonçalves, Soledade, Anta Gorda, Ilópolis, Putinga.
} 
As primeiras páginas de cada álbum são dedicadas aos objetivos do mesmo, e em todos se sugere uma trajetória histórica coerente, partindo de um passado fundacional - a chegada dos imigrantes italianos no Rio Grande do Sul - e culminando na presente celebração no espaço urbano e moderno.

Os dois primeiros álbuns são escritos em tom de engrandecimento a esta leva imigratória, tornando-a fundamental para o progresso do estado. Ambos foram lançados no bojo de comemorações excepcionais, já que nos festejos dos 75 anos se tem a retomada da Festa da Uva e no Centenário uma grande comemoração promovida pelo estado, que foi o Biênio da Colonização e Imigração. Estes dois álbuns lançados em períodos ainda muito próximos ao final da Segunda Guerra Mundial, onde o fascismo em muitos momentos representou no Sul do Brasil retaliação aos descendentes de imigrantes italianos, nos traz a perspectiva de que eles possuíam um objetivo muito importante, qual seja, mostrar os aspectos positivos da imigração italiana.

Enquanto o álbum dos 75 anos apresenta a imigração italiana de modo geral através da sua história, o do Centenário além desta apresentação tem ainda a função de promover a integração destes descendentes de imigrantes ao restante do povo brasileiro, sendo esta uma das premissas das comemorações do Biênio da Colonização e Imigração.

Já o álbum aos 130 anos da imigração italiana se difere em relação aos outros dois por se tratar de um momento histórico distinto. Ainda que com a função de homenagear e agradecer aos imigrantes, não havia mais o contexto histórico carregado pelos outros dois álbuns, já que o imigrante encontrava-se integrado a identidade gaúcha. O terceiro álbum é muito menos laudatório, e isso se deve às pessoas escolhidas para desenvolverem a sua escrita, como alguns intelectuais e estudiosos de renome que pesquisam a imigração italiana, trazendo à tona novas perspectivas na maneira de perceber este imigrante, como a temática da mulher imigrante, um tema bastante atual. O patrocínio deste álbum pela Souza Cruz também impediu que os discursos sobre o progresso estivessem atrelados às indústrias. Este álbum previa com suas escritas e imagens promover uma maior integração entre os descendentes de italianos e os próprios italianos, principalmente no que refere aos intercâmbios econômicos, que trariam bem feitorias ao estado.

Em relação às imagens selecionadas para compor os álbuns vemos algumas constâncias que remetem ao progresso, tradição e identidade. Os próprios álbuns propõem o exercício comparativo, dando a ler através das imagens "como fomos" em oposição ao "como somos”. Sem esquecer a tradição, os produtos típicos estão sempre presentes nos três álbuns. Nos dois primeiros temos inúmeras páginas dedicadas às cidades ligadas à imigração italiana e nestes podemos ver explícito o desejo de se reconhecer o progresso através de fotografias de prédios grandiosos, muitas propagandas de indústrias e comércios. Não é possível observar este discurso nas imagens do álbum mais atual, que preferiu abordagens mais conceituais destas imagens, como fragmentos, mãos e objetos. O terceiro álbum inclusive se propõe a contar uma história através de imagens, dedicando várias páginas a elas.

Sobre a história da imigração contada nos álbuns percebemos que o contexto histórico é de fundamental importância para termos em conta o discurso neles produzidos. Ainda que as comemorações proponham um discurso de homenagem e agradecimento, para além disso, o contexto histórico diversificou a proposta dos três álbuns em: apresentação da imigração italiana, aproximação dos imigrantes com os brasileiros e aproximação dos descendentes de imigrante com os italianos. De modo geral a história contada é de vitória e progresso. 


\section{Referências bibliográficas}

BARROS, José D’Assunção. História Comparada. Petrópolis, Rio de Janeiro: Vozes, 2014.

BERTASSO, Henrique D'avila. LIMA, Mário de Almeida. (Org.). Álbum Comemorativo do $75^{\circ}$ aniversário da Colonização Italiana no Rio Grande do Sul. Porto Alegre: Revista O Globo, 1950.

BRASIL. Decreto $n^{\circ} 22.410$, de 22 de Abril de 1973. Institui o Biênio da Colonização e Imigração. Disponível: $<\mathrm{http}: / /$ www.al.rs.gov.br/Legis>. Acesso em: 10 maio. 2015.

BOSI, Alfredo. Dialética da Colonização. São Paulo: Companhia das Letras, 1992.

CANDAU, Joël. Antropologia da Memória. Lisboa: Instituto Piaget, 2013.

DUARTE, José Bacchieri (Org.). Centenário da Imigração Italiana: álbum oficial. Porto Alegre: EDEL, 1975.

GIAUDRONE, Carla. Identidad y cultura del Centenario. Imágenes del gaucho en álbumes conmemorativos argentinos. In: GUTMAN, Maragarita. MOLINOS, Rita. (Org.). Construir Bicentenarios Latinoamericanos en la era de la Globalización. Buenos Aires: Infinito, 2012.

KNACK, Eduardo Roberto Jordão. Cidades em Álbuns Comemorativos: história, memória e visualidade. In: Revista Latino-americana de História. São Leopoldo. v. 2. n. 7. set. 2013. Edição Especial.

PESAVENTO, Sandra Jatahy. O mundo da imagem: território da história cultural. In: Narrativas, imagens e práticas sociais: percursos em História Cultural. Porto Alegre, RS: Asterisco, 2008.

RIBEIRO, Cleodes Piazza Júlio. Imigração Italiana no Rio Grande do Sul: resgate da memória. In: REICHEL, Heloisa Jochims. GUTFREIND, Ieda (org.). América Platina e Historiografia: história agrária, imigração e etnia, história política e mentalidades. São Leopoldo: UNISINOS, 1996.

ROEHE, Nara Simone Viegas Rocha. O Sesquicentenário da Imigração Alemã no Rio Grande do Sul em 1974 como corolário das relações econômicas Brasil-Alemanha. Porto Alegre. Dissertação (Mestrado), PPG História, PUCRS, 2006, p. 63.

SAYAD, Abdelmalek. A imigração ou os paradoxos da alteridade. São Paulo: Editora da Universidade, 1998.

SULIANI, Antônio. COSTA, Frei Rovílio. Cultura Italiana: 130 anos. Porto Alegre: Nova Prova, 2005.

TÉLLEZ, Armando Silva. Álbum de família: la imagen de nosotros mismos. Santa Fé de Bogotá: Norma, 1998.

TRAVERSO, Enzo. O passado, modos de usar: História, memória e política. Tradução de Tiago Avó. Lisboa: Edições Unipop, 2012.

Submissão: 22/05/2016

Aceite: $25 / 10 / 2016$ 